\title{
Philadelphia-negatív krónikus Myeloproliferativ Neoplasia Magyarországi Regiszter
}

\section{Polycythaemia verás betegeink adatainak elemzése}

\author{
Dombi Péter dr. ${ }^{1}$ - Illés Árpád dr. ${ }^{2}$ - Demeter Judit dr. ${ }^{3}$ - Homor Lajos ${ }^{4}$ \\ Simon Zsófia $\mathrm{dr}^{2}{ }^{2}$ - Kellner Ádám $\mathrm{dr}^{5}{ }^{5}$. Karádi Éva dr. ${ }^{5}$ \\ Valasinyószki Erika dr. ${ }^{1}$ - Udvardy Miklós dr. ${ }^{2}$ - Egyed Miklós dr. ${ }^{5}$ \\ ${ }^{1}$ Szent Borbála Kórház, Tatabánya \\ ${ }^{2}$ Debreceni Egyetem, Általános Orvostudományi Kar, Hematológiai Tanszék, Debrecen \\ ${ }^{3}$ Semmelweis Egyetem, Általános Orvostudományi Kar, I. Belgyógyászati Klinika, Budapest \\ ${ }^{4}$ Pázmány Péter Katolikus Egyetem, Bölcsészet- és Társadalomtudományi Kar, Piliscsaba (Esztergom) \\ ${ }^{5}$ Somogy Megyei Kaposi Mór Oktató Kórház, Hematológiai Osztály, Kaposvár
}

\begin{abstract}
Bevezetés és célkitüzés: A HUMYPRON munkacsoport által 2013-ban létrehozott Philadelphia-negatív myeloproliferativ neoplasiás betegek magyar regiszteréből a polycythaemia verás betegek adatait elemezzük.

Módszer: A 15 hematológiai centrumból regisztrált 351 JAK2 ${ }^{\mathrm{V} 617 \mathrm{~F}}$ - és exon-12-mutációpozitív polycythaemia verás beteg epidemiológiai, klinikai, diagnosztikus és kezelési jellemzőit, vascularis és transzformációs eseményeit dolgoztuk fel. A diagnózist megelőző és azt követő thromboemboliás eseményeket a Landolfi szerinti rizikófelmérés alapján értelmeztük.

Eredmények: A diagnózist megelőzően 106 betegben 116, a diagnózist követő időszakban 106 betegben 152 thromboemboliás eseményt regisztráltunk. A major artériás események szignifikánsan csökkentek $(\mathrm{p}<0,0001)$, a minor vénás események szignifikánsan fokozódtak $(\mathrm{p}<0,0001)$ a diagnózist követően. A betegség transzformációját 26 esetben, a major vérzést 25 esetben észleltük.

Következtetések: Online regiszterünk könnyen kezelhető, lehetővé teszi a hazai betegek jellemzőinek felmérését és az eredmények gyors kiértékelését. A Landolfi-rizikóbecslés eredményesnek bizonyult. Kérdőívünket a kiértékelést követően pontosítottuk. A diagnosztikus kritériumok, a rizikóbecslés és az ennek megfelelő kezelési ajánlás pontosabb betartása szükséges, amelyre ajánlásokat tettünk.
\end{abstract}

Orv Hetil. 2017; 158(23): 901-909.

Kulcsszavak: polycythaemia vera, regiszter, myeloproliferativ neoplasia, cardiovascularis rizikófaktor, Landolfirizikóbecslés

\section{Hungarian Philadelphia negative chronic myeloproliferative neoplasia registry}

\section{Evaluation of the polycythemia vera patients}

Intruduction and aim: The Hungarian National Registry for Philadelphia chromosome negative myeloproliferative neoplasms has been developed. The aim of the recent study is to assess the clinical characteristics of Hungarian patients with polycythemia vera.

Method: Data of 351 JAK2 $2^{\mathrm{V} 617 \mathrm{~F}}$ and exon 12 mutation positive polycythemia vera patients were collected online from 15 haematology centres reporting epidemiologic, clinical characteristics, diagnostic tools, therapeutic interventions, thromboembolic complications, disease transformations. Vascular events prior to and after diagnosis were evaluated upon the Landolfi risk assessment scale.

Results: 116 thromboembolic events were reported in $106 \mathrm{PV}$ patients prior to diagnosis and 152 occasions in 102 patients during follow-up. The frequency of major arterial events were significantly reduced $(\mathrm{p}<0.0001)$ and the minor venous events were significantly elevated $(\mathrm{p}<0.0001)$ after the diagnosis. Major hemorrhagic complications were found in 25 and transformation in 26 cases. 
Conclusions: Our registry allows to collect and evaluate the features of patients with polycythemia vera. The Landolfi risk stratification was proven to be useful. Based on evaluated data, accuracy of diagnostic criteria and compliance to risk-adapted therapeutic guidelines are needed.

Keywords: polycythemia vera, registry, myeloproliferative neoplasms, cardiovascular risk factors, Landolfi risk stratification

Dombi P, Illés Á, Demeter J, Homor L, Simon Zs, Kellner Á, Karádi É, Valasinyószki E, Udvardy M, Egyed M. [Hungarian Philadelphia negative chronic myeloproliferative neoplasia registry. Evaluation of the polycythemia vera patients]. Orv Hetil. 2017; 158(23): 901-909.

(Beérkezett: 2017. március 23.; elfogadva: 2017. április 27.)

\section{Rövidítések}

Amaj = major artériás thromboemboliás esemény; Amin $=$ minor artériás thromboemboliás esemény; $\mathrm{AML}=$ akut myeloid leukaemia; ASA = aszpirin; ATE = artériás thromboembolia; $\mathrm{ET}=$ essentialis thrombocythaemia; fvs. = fehérvérsejtszám a diagnózis időpontjában; $\mathrm{Hb}=$ hemoglobin; $\mathrm{Htc}=$ hematokrit; $\mathrm{HU}=$ hidroxiurea; HUMYPRON GROUP = Hungarian Myeloproliferative Neoplasia Group; HZV = herpes zoster vírus; JAK = Janus-kináz; MPL = megakaryocyta thrombopoetinreceptor; $\mathrm{MPN}=$ myeloproliferativ neoplasia $; \mathrm{NGAL}=$ neut rophil gelatinase-associated lipocalin; $\mathrm{PMF}=$ primer myelofibrosis; post-PV-MF = polycythaemia vera után kialakuló myelofibrosis $; \mathrm{PV}=$ polycythaemia vera $; \mathrm{R} / \mathrm{R} \mathrm{PV}=$ rezisztens nonreszponder/relabált polycythaemia vera; $\mathrm{TE}=$ thromboemboliás esemény; Vmaj = major vénás thromboemboliás esemény; $\mathrm{Vmin}=$ minor vénás thromboemboliás esemény

A polycythaemia vera (PV) a haemopoeticus össejtek klonális, malignus megbetegedése. A Philadelphia-negatív klasszikus myeloproliferativ neoplasiák (MPN) körébe tartozik az essentialis thrombocythaemiával (ET) és a primer myelofibrosissal (PMF) együtt. A kórkép kialakulására jellemző a JAK-STAT jelátviteli útvonal folyamatos, konstitucionális aktivációja, amely a myeloproliferatióhoz vezet $[1,2]$.

Diagnózisa a WHO 2016-os revideált klasszifikáció alapján történik $[3,4]$.

A PV diagnózisa három major és egy minor kritériumon alapul. Major kritériumok: 1. emelkedett keringő vérvolumen $(\mathrm{Hb}, \mathrm{Htc}) ; 2$. csontvelö-biopszia jellegzetes képe; 3. JAK2 $2^{\mathrm{V} 617 \mathrm{~F}}$ - vagy exon-12-mutáció kimutatása. Minor kritérium az alacsony szérumeritropoetin-szint. A PV diagnózisa bizonyított, ha mindhárom major kritérium teljesül, vagy ha két major kritérium: emelkedett hemoglobin (férfiak esetén $\mathrm{Hb}$ magasabb, mint $165 \mathrm{~g} / \mathrm{l}$, Htc: 49\%; nők esetén magasabb, mint $160 \mathrm{~g} / \mathrm{l}$, Htc: 48\%) mellett PV-re típusos a csontvelői szövettan + alacsony az eritropoetinszint. Vitatott a csontvelő szövettani vizsgálatának szükségessége, amely tulajdonképpen nem feltétele a biztos diagnózisnak (akkor, ha férfi esetén a $\mathrm{Hb}$ magasabb, mint $185 \mathrm{~g} / \mathrm{l}$ és a Htc: $55,5 \%$, illetve nők esetén a Hb magasabb, mint $165 \mathrm{~g} / \mathrm{l}$ és Htc: 49,5\% feletti; a 2016-os WHO-ajánlás sem feltétlenül javasolja a crista ilei biopszia végzését, és ebben megegyezik a 2008-as ajánlással [1]), de differenciáldiagnosztikai szempontból a PMF praefibroticus fázisától való elkülönítésben fontos szerepe lehet.

Ritka kórkép, az Európai Unióban a PV incidenciája $0,4-2,8 / 100000$ fó/év. Idős életkorban sokkal gyakoribb $[5,6]$.

A PV-re leginkább a ligand (eritropoetin) független, kóros erythroid proliferáció, következményes polyglobulia jellemző. Az emelkedett keringő vérvolumen fokozódó viszkozitást, hypertoniát eredményez. Gyakran a fehérvérsejt- és vérlemezkeszám emelkedése is megfigyelhető $[7,8]$.

PV-ben már évekkel a diagnózist megelőzően és a betegség teljes lefolyása során végig gyakoriak a thromboemboliás (TE)/cardiovascularis (CV) szövődmények. A thrombosishajlam fokozódását (mind artériás, mind vénás thrombosishajlam emelkedett) a magas hematokrittal, az emelkedett thrombocytaszámmal [8], a magas fehérvérsejtszámmal és JAK2 ${ }^{\mathrm{V} 617 \mathrm{~F}}$-expressziós szinttel magyarázzák $[9,10]$. Felmerült a vashiány, amit az erythropoesis gyors proliferációja [11] vagy a túlzott phlebotomiák okozhatnak [12] és az NGAL (lipocalin-2) szerepe is [13].

A betegség hosszával arányosan másodlagos (post-PV) myelofibrosis, illetve szekunder akut myeloid leukaemia (sAML) is kialakulhat. A PV-betegek élettartama jelentősen csökken az egészséges populációban várhatótól, az átlagtúlélés 14 év, a fiatal, alacsony rizikójú betegeké 20 év feletti [14-16]. Az általános/kíséró tünetek (leginkább a gyengeség, a fogyás, hasi és csontfájdalmak, bőrviszketés, hőemelkedés stb.) a betegek életminőségét jelentősen rontják.

A PV kezelésében phlebotomia, aszpirin, hidroxiurea, interferon, JAK-inhibitorok alkalmazhatók [17, 18].

A betegség spontán lefolyása hosszú, ezért a randomizált tanulmányok mellett a betegek követésének fontos szerepe van a lefolyás, a kezelések megítélésében. 
Ezért alapítottuk meg a HUMYPRON csoportot [19], és PV-betegeink retrospektív elemzését is ezért végeztük el és mutatjuk be.

\section{Betegek és módszer}

A HUMYPRON GROUP 426 PV-beteg adatait tartalmazza, az adatbevitel 2013-2015 között történt 15 magyar hematológiai ellátóhelyből. Közleményünk a betegek adatainak elemzése (179 nő, 247 férfi, átlagéletkor 62 év, 18-87 év). Az elemzés az összes PV-sként bevitt beteg adataira kiterjed. Elemezzük a diagnóziskor észlelt vérképeltéréseket, JAK-mutációs státuszt, a diagnózist megelőző és követő TE-eseményeket, vérzéses szövődményeket és transzformációt (myelofibrosis, akut leukaemia).

A thromboemboliás eseményeket (TE) Gisslinger szerint csoportosítottuk [20].

\section{Thromboticus események definíciója}

Major artériás thrombosis (Amaj): stroke, myocardialis infarctus, perifériás artériás érbetegség és egyéb artériás thrombosis.

Minor artériás esemény (Amin): tranziens ischaemiás attak (TIA), angina pectoris, erythromegalia, egyéb perifériás artériás mikrocirkulációs és thromboticus zavarok.

Major vénás thrombosis (Vmaj): mélyvénathrombosis és tüdőembólia, splanchnicus vénás thrombosis és egyéb major vénás thrombosisok.

Minor vénás események (Vmin): superficialis thrombophlebitisek.

A thrombosisrizikó felmérésére a Landolfi-féle stratifikációt [21] használtuk (1. táblázat).

A rizikócsoportnak megfelelő terápiás ajánlást a 2. táblázat mutatja be.

1. táblázat |A Landolfi-féle TE-rizikó-stratifikáció [21]

\begin{tabular}{ll}
\hline Thrombosisrizikó-becslés PV-ben Landolfi alapján & \\
\hline Rizikófaktor & Pontszám \\
\hline Életkor (év) & \\
$\quad<40$ & 0 \\
$40-55$ & 1,0 \\
$56-65$ & 2,5 \\
$>65$ & 3,5 \\
Hypertonia & 0,5 \\
Dyslipidaemia & 0,5 \\
Thrombocytaszám $\left(>1000 \times 10^{9} / 1\right)$ & 1,0 \\
Leukocytaszám $\left(>12 \times 10^{9} / 1\right)$ & 1,0 \\
Dohányzás & 1,5 \\
Diabetes mellitus, 2 -es típus & 1,5 \\
Megelózón thrombosis & 3,5 \\
\hline
\end{tabular}

2. táblázat | Terápiás ajánlás [21]

\begin{tabular}{lll}
\hline Pontérték & Rizikóbesorolás & Terápiás ajánlás PV-ben \\
\hline$<1$ & Alacsony & $\begin{array}{l}\text { Phlebotomia, ASA } \\
\text { megfontolandó }\end{array}$ \\
\hline $1-3$ & Közepes & Phlebotomia + ASA \\
\hline $3,1-5,5$ & Magas & $\begin{array}{l}\text { Citoreduktív kezelés }+ \\
\text { Phlebotomia }+ \text { ASA }\end{array}$ \\
\hline$>5,5$ & Extrém magas & $\begin{array}{l}\text { Citoreduktív kezelés }+ \\
\text { Phlebotomia }+ \text { ASA }\end{array}$ \\
& & $\begin{array}{l}\text { Még agresszívebb kezelés } \\
\text { mérlegelése }\end{array}$ \\
\hline
\end{tabular}

A betegek kezelése phlebotomiával, aszpirinnel (ASA) és citoreduktív szerekkel - hidroxiurea (HU), interferon (IFN), cytosine-arabinosid (Ara-C), busulfan, JAK-inhibitorokkal történt. A TE-eseményeket aszerint is értékeltük, hogy milyen kezelés mellett léptek fel.

\section{Statisztikai elemzés}

A folyamatos változókat középértékkel jellemeztük, öszszehasonlításukra Mann-Whitney-tesztet használtunk. Fisher-féle egzakt tesztet a dichotom változókra alkalmaztunk. A Landolfi-stratifikáció TE-rizikófaktorait univariáns analízissel vizsgáltuk. Az analízist az SPSS (20.0 verzió) használatával végeztük.

A regiszter az Egészségügyi Tudományos Tanács Tudományos és Kutatásetikai Bizottság engedélyével és a Helsinki Deklaráció betartásával készült.

\section{Eredmények}

\section{Polycythaemia verás betegek demográfiai adatai}

A 426 PV-beteg közül 82\% (351) JAK2 $2^{\mathrm{V} 617 \mathrm{~F}}$ - és exon12-pozitív, $11 \%$ (45) JAK2 ${ }^{\mathrm{V} 617 F_{-}}$és exon-12-negatív. A JAK-státusz hiányzott $30(7 \%)$ beteg esetében, így nem feleltek meg a PV WHO diagnosztikus kritériumainak. Ezeket a betegeket „insufficiens”-nek nyilvánítottuk, a továbbiakban csak a 351 JAK2 ${ }^{\mathrm{V} 617 \mathrm{~F}}$ - és exon12-mutáció-pozitív PV-beteg adatait elemezzük.

A 3. táblázatban mutatjuk be a 351 PV-beteg adatait. A 183 férfi beteg átlagéletkora 60,8 év $( \pm 12,8)$ (19-87 év) és a 168 nóbeteg átlagéletkora 62,8 ( $\pm 11,7)(24-$ 84) volt.

\section{TE-események}

A PV-diagnózis előtt 106 betegen 116 TE-eseményt regisztráltunk, némelyik akár 18 évvel is megelőzte a diagnózis felállítását.

A TE-események több mint 50\%-a a felismerést megelőző két évben történt. 


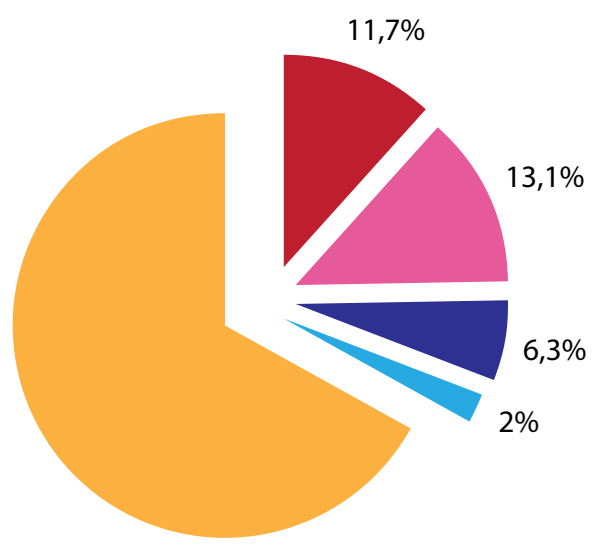

Amaj
Amin
Vmaj
Vmin
Nem volt
TE

1. ábra | A diagnózis előtti TE-események megoszlása
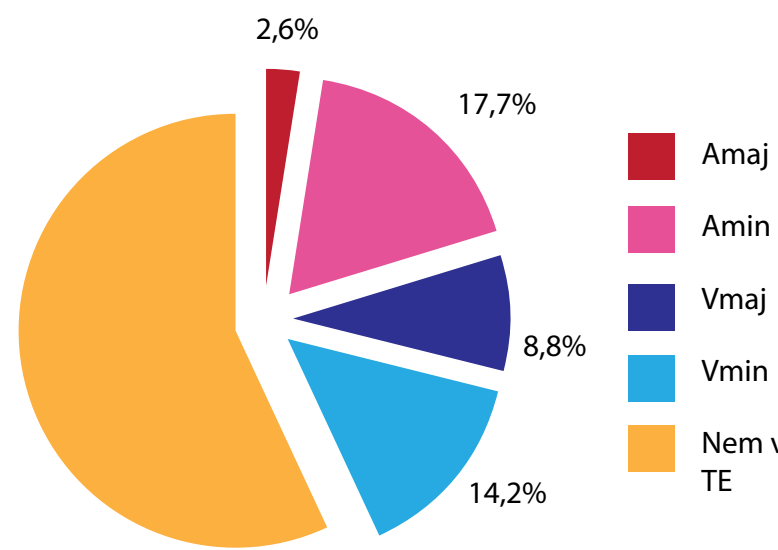

Vmin

Nem volt TE

2. ábra

| A diagnózis utáni TE-események megoszlása

A diagnózist megelőző major artériás TE-esemény 41 alkalommal $(11,7 \%)$ lépett fel, míg minor artériás TEeseményt 46 esetben $(13,1 \%)$ észleltek. Major vénás TE 22 esetben $(6,3 \%)$, míg minor vénás TE 7 esetben $(2 \%)$ igazolódott (1. ábra).

A diagnózist követő TE-események összetétele jelentôsen megváltozott.

A major artériás TE-események aránya 11,7\%-ról 2,6\%-ra csökkent $(\mathrm{p}<0,0001)$.

A minor artériás TE-események aránya és száma is emelkedett, 13,1\%-ról 17,7\%-ra, de ez nem volt szignifikáns változás $(\mathrm{p}=0,12)$.

A major vénás TE-események lényegében nem változtak, $6,3 \%$ vs. $8,8 \%(\mathrm{p}=0,25)$, miközben a minor vénás TE-események aránya 2,0\%-ról 14,2\%-ra $\quad(\mathrm{p}<0,0001)$ szignifikánsan emelkedett (2. ábra).

A diagnózis előtti TE-eseményen átesett 106 beteg közül 43 beteg $(42,2 \%)$ recidív TE-eseményt szenvedett el a diagnózist követően, kezelés mellett (4. táblázat).

Vérzéses szövődményt 20 esetben (5,7\%-ban) észleltünk.
Myelofibrosisba való transzformációt 23 esetben $(6,5 \%)$, akut myeloid leukaemiát és malignus non-Hodgkin-lymphomát egy-egy esetben regisztráltunk.

A diagnóziskor mért TE-események a vérképadatok tükrében a 4. táblázatban láthatók.

A magas, 45-55\% közötti Htc és a TE-események között semmiféle összefüggést nem találtunk.

A 3. táblázatban a Landolfi-rizikócsoport szerint mutatjuk be a TE-eseményeket (3. táblázat). 82 PV-beteget alacsony vagy közepes TE-rizikójúnak találtunk, 241 betegünk a magas vagy extrém magas rizikócsoportba került, 28 beteg esetében hiányzott a Landolfi-rizikóbecslés.

A TE-események és a Landolfi-rizikóbecslés összefüggéseit a 3. táblázatban mutatjuk be.

A diagnózist megelőző TE-események értelemszerüen csak a magas rizikócsoportban fordulhattak elő, közülük $42 \%$ ismétlődött. A diagnózist követően a magas rizikójú betegek folyamatosan kezelést kaptak, ennek ellenére az artériás TE-események szignifikánsan nagyobb arányban fordultak elő közöttük ( $\mathrm{p}=0,039)$.

A diagnózist megelőző és követő TE-eseményeket az egyes Landolfi-rizikótényezőkkel vetettük össze $a$ 4. táblázatban.

A diagnózist megelőző artériás TE-események a korral (60 év felett) $(\mathrm{p}=0,037)$, a hypertoniával $(\mathrm{p}=0,009)$ és a diagnóziskor mért 10,0 G/1 feletti fehérvérsejtszámmal $(\mathrm{p}=0,038)$, a vénás TE-események csak a diagnóziskor mért, 10,0 G/1-t meghaladó fehérvérsejtszámmal $(\mathrm{p}=0,010)$ mutattak szignifikáns összefüggést $(\mathrm{p}<0,05)$.

A diagnózist követő artériás TE-események a korral (60 év felett) $(\mathrm{p}=0,046)$ és a megelőző TE-eseménnyel $(\mathrm{p}=0,012)$, a vénás események csak a diagnóziskor mért 10,0 G/1-t meghaladó fehérvérsejtszámmal $(\mathrm{p}=0,026)$ korreláltak $(\mathrm{p}<0,05)$.

Külön elemeztük 43 beteg TE-eseményeit, akik Teffe$r i$ szerint $(3,8)$ alacsony (60 évnél fiatalabb és előző TEeseményt el nem szenvedett), Landolfi szerint [21] magas/extrém magas TE-rizikójú betegcsoportba tartoztak. 17 TE-eseményt észleltünk 15 betegen, akik közül 12en nem kaptak kezelést. TE-eseményt 28 betegen nem észleltünk, közülük 25 folyamatosan HU + ASA alapú kezelést kapott.

\section{A terápia hatása a TE-eseményekre}

Általában a nemzetközi ajánlásoknak $[3,17,18]$ megfelelő módokon kezeltük PV-betegeinket (3. táblázat).

A betegek $60 \%$-ában sorozatos phlebotomia történt, $70 \%$-uk rendszeresen aszpirint szedett, a magas rizikójú 241 beteg HU-kezelést, 5,8\%-uk interferont, 2,5\% JAKinhibitort és 2,2\% egyéb citoreduktív kezelést kapott.

A PV-betegek kezelését a 3. táblázatban mutatjuk be.

A legtöbb beteg váltakozó formájú kezeléseket kapott, kezdetben többnyire phlebotomia + ASA, később HU + ASA kezeléseket. Mivel kérdőívünk ezen modali- 
3. táblázat | JAK2 ${ }^{\mathrm{V} 617 \mathrm{~F}}$-pozitív PV-betegeink demográfiai, diagnózist követő TE-eseményei és terápiás adatainak megoszlása a Landolfi-rizikócsoport szerint

\begin{tabular}{|c|c|c|c|c|}
\hline & PV-betegek $(\mathrm{n}=351)$ & $\begin{array}{c}\text { Landolfi-rizikóérték } \\
\text { (alacsony/közepes) } \\
0-3,0\end{array}$ & $\begin{array}{c}\text { Landolfi-rizikóérték } \\
\text { (magas/extrém magas) } \\
>3,0\end{array}$ & $\mathrm{p}$ \\
\hline Betegszám $(\mathrm{N})$ & 323 & 82 & 241 & \\
\hline Nem, férfi/nő (\%) & $183 / 168(52 / 48)$ & $47 / 35(57 / 43)$ & $123 / 118(51 / 49)$ & 0,371 \\
\hline Életkor a diagnóziskor, év & 61,9 & 51,5 & 65,3 & $<0,001$ \\
\hline \multicolumn{5}{|l|}{ Terápia, n/N (\%) } \\
\hline Phlebotomia & $208 / 342(60,8)$ & $49 / 80(61,3)$ & $142 / 236(60,2)$ & 0,895 \\
\hline Aszpirin & $238 / 342(69,6)$ & $54 / 80(67,5)$ & $162 / 236(68,6)$ & 0,889 \\
\hline Hidroxiurea & $299 / 342(87,4)$ & $65 / 80(81,3)$ & $209 / 236(88,6)$ & 0,126 \\
\hline Egyéb citoreduktív szerek ${ }^{\dagger}$ & $6 / 275(2,2)$ & $1 / 65(1,5)$ & $5 / 199(2,5)$ & 1,0 \\
\hline Interferon & $20 / 342(5,8)$ & $7 / 82(8,5)$ & $13 / 241(5,4)$ & 0,299 \\
\hline JAK-inhibitor & $8 / 323(2,5)$ & $1 / 82(1,2)$ & $7 / 241(2,9)$ & 0,685 \\
\hline \multicolumn{5}{|l|}{$\begin{array}{l}\text { TE-események száma a diagnózist követően, } \\
\mathrm{n} / \mathrm{N}(\%)\end{array}$} \\
\hline Major artériás TE & $9 / 351(2,6)$ & $2 / 82(2,4)$ & $5 / 241(2,1)$ & 1,0 \\
\hline Minor artériás TE & $62 / 351(17,7)$ & $9 / 82(11,0)$ & $51 / 241(21,2)$ & 0,048 \\
\hline Artériás TE & $67 / 351(19,1)$ & $10 / 82(12,2)$ & $55 / 241(22,8)$ & 0,039 \\
\hline Major vénás TE & $31 / 351(8,8)$ & $6 / 82(7,3)$ & $21 / 241(8,7)$ & 0,820 \\
\hline Minor vénás TE & $50 / 351(14,2)$ & $8 / 82(9,8)$ & $38 / 241(15,8)$ & 0,204 \\
\hline Vénás TE & $77 / 351(21,9)$ & $14 / 82(17,1)$ & $56 / 241(23,2)$ & 0,279 \\
\hline $\mathrm{TE}$ & $102 / 351(29,1)$ & $18 / 82(22,0)$ & $77 / 241(32,0)$ & 0,094 \\
\hline Artériás és vénás TE (kombinált) események & $42 / 351(11,9)$ & $6 / 82(7,3)$ & $34 / 241(14,1)$ & 0,123 \\
\hline
\end{tabular}

$\mathrm{JAK}=$ Janus-kináz; $\mathrm{PV}=$ polycythaemia vera; $\mathrm{TE}=$ thromboemboliás esemény ${ }^{\dagger}{ }^{\dagger}=$ egyéb citoreduktív szerek: cytosine-arabinoside $($ Ara- $\mathrm{C})$ és busulfan

tások pontos hosszát és egymáshoz viszonyított sorrendjét nem mérte fel, ezért az egyes modalitásokat külön értékelni nem tudtuk.

\section{Következtetések}

A robbanásszerúen növekvő tudományos ismeretanyag egyre bonyolultabb gyưjtő/tároló és kiértékelő rendszerek kialakítását igényli. Ezért hoztuk létre az internetalapú HUMYPRON MPN regisztert, amely a betegadatok egyszerű bevitelét és gyors kiértékelését teszi lehetővé. Jelenleg már több mint 900 beteg adatait tartalmazza, így nemzetközileg is jelentősnek minősíthető [19].

A regiszter 351 PV-betegének adatai a nemzetközi adatokkal megegyező férfi predominanciát mutatnak és a férfiak diagnóziskori alacsonyabb átlagéletkorát. Mivel a betegek adatainak bevitele és diagnózisuk között átlagban több mint öt év (egyes esetekben akár 25 év) telt el, a PV diagnózisa nem minden esetben a WHO 2008-as klasszifikációja szerint történt, így a 426 regisztrált PV-

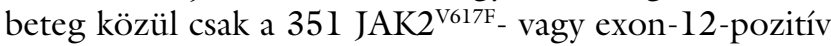
és a PV további diagnosztikus kritériumainak megfelelő betegeket értékeltük. A PV vezető problémája a diagnózist évekkel megelőző és azt követően is magas artériás és vénás thromboembolia-hajlam. A diagnózist megelőzően a betegek 30,2\%-ának, a diagnózist követően 29,06\%- ának volt TE-eseménye. A TE-események aránya, összetétele jelentősen változott. A diagnózist megelőzően a betegek 24,8\%-ának volt artériás TE-eseménye (11,7\% major $+13,1 \%$ minor), és csak $8,3 \%$ vénás TE-t $(6,3 \%$ major $+2,0 \%$ minor) regisztráltunk. A közel háromszor gyakoribb artériás TE-frekvencia lényegesen eltér a nemzetközi közlemények adataitól, ahol PV-ben általában közel azonos arányban fordul elő a kétféle TE-esemény $[8,9]$. Az eltérésre egyértelmú magyarázatot nem találtunk, de feltehetően a 60 év körüli magyar populáció magasabb cardiovascularis érintettsége is fontos szerepet játszhat.

A diagnózist követően a betegek 20,3\%-ának volt artériás TE-eseménye $(2,6 \%$ major $+17,7 \%$ minor $)$ és $23,0 \%$ nál vénás TE-t regisztráltunk $(8,8 \%$ major $+14,2 \%$ minor). A közel $1: 1$ arány már megfelel a nemzetközi adatoknak $[8,9]$.

A diagnózis előtti artériás TE-események a hypertoniával, a $10 \mathrm{G} / 1$ feletti fvs.-számmal és a magas életkorral, a diagnózis utáni artériás TE-események a magas életkorral és a megelőző TE-eseményekkel mutattak szignifikáns összefüggést. A diagnózis előtti és utáni vénás TE-események csak a $10 \mathrm{G} / 1$ feletti fvs.-számmal mutattak szignifikáns összefüggést. Ezek az adatok általában egyeznek a nemzetközi nagy tanulmányok adataival [16, 22 ]. 
4. táblázat | JAK2 ${ }^{\mathrm{V} 617 \mathrm{~F}}$-pozitív PV-betegeink TE-eseményei az egyes rizikótényezők alapján

\begin{tabular}{|c|c|c|c|c|c|c|c|c|}
\hline \multirow[t]{2}{*}{ Rizikótényezők } & \multicolumn{4}{|c|}{ TE-események a PV diagnózisa előtt } & \multicolumn{4}{|c|}{ TE-események a PV diagnózisát követően } \\
\hline & Artériás TE & $\mathrm{p}$ & Vénás TE & $\mathrm{p}$ & Artériás TE & $\mathrm{p}$ & Vénás TE & $\mathrm{p}$ \\
\hline Életkor, év & & 0,037 & & 0,634 & & 0,046 & & 0,061 \\
\hline$<40$ & $1 / 18(5,6 \%)$ & & $0 / 18(0 \%)$ & & $3 / 18(16,7 \%)$ & & $5 / 18(27,8 \%)$ & \\
\hline $40-55$ & $14 / 84(16,7 \%)$ & & $7 / 84(8,3 \%)$ & & $10 / 84(11,9 \%)$ & & $12 / 84(14,3 \%)$ & \\
\hline $56-65$ & $22 / 100(22,0 \%)$ & & $9 / 100(9,0 \%)$ & & $16 / 100(16,0 \%)$ & & $18 / 100(18,0 \%)$ & \\
\hline$>65$ & $43 / 146(29,5 \%)$ & & $12 / 146(8,2 \%)$ & & $38 / 146(26,0 \%)$ & & $41 / 146(28,1 \%)$ & \\
\hline Magas vérnyomás & & 0,009 & & 0,161 & & 0,43 & & 0,220 \\
\hline Nem & $10 / 84(11,9 \%)$ & & $10 / 84(11,9 \%)$ & & $14 / 84(16,7 \%)$ & & $14 / 84(16,7 \%)$ & \\
\hline Igen & $62 / 238(26,1 \%)$ & & $16 / 238(6,7 \%)$ & & $51 / 238(21,4 \%)$ & & $56 / 238(23,5 \%)$ & \\
\hline Hematokrit & & 0,636 & & 0,467 & & 1,0 & & 0,525 \\
\hline $45-50 \%$ között & $54 / 248(21,8 \%)$ & & $22 / 248(8,9 \%)$ & & $50 / 248(20,2 \%)$ & & $52 / 248(21,0 \%)$ & \\
\hline 50-55\% között & $18 / 74(24,3 \%)$ & & $4 / 74(5,4 \%)$ & & $15 / 74(20,3 \%)$ & & $18 / 74(24,3 \%)$ & \\
\hline $\begin{array}{l}\text { Thrombocyta* } \\
\qquad\left(>1000 \times 10^{9} / 1\right)\end{array}$ & & 0,075 & & 0,609 & & 0,714 & & 0,076 \\
\hline Nem & $72 / 310(23,2 \%)$ & & $26 / 310(8,4 \%)$ & & $62 / 310(20,0 \%)$ & & $70 / 310(22,6 \%)$ & \\
\hline Igen & $0 / 12(0 \%)$ & & $0 / 12(0 \%)$ & & $3 / 12(25,0 \%)$ & & $0 / 12(0 \%)$ & \\
\hline $\begin{array}{l}\text { Fehérvérsejt* } \\
\qquad\left(>10 \times 10^{9} / 1\right)\end{array}$ & & 0,038 & & 0,010 & & 0,569 & & 0,026 \\
\hline Nem & $53 / 203(26,1 \%)$ & & $10 / 203(4,9 \%)$ & & $39 / 203(19,2 \%)$ & & $36 / 203(17,7 \%)$ & \\
\hline Igen & $19 / 119(16,0 \%)$ & & $16 / 119(13,4 \%)$ & & $26 / 119(21,8 \%)$ & & $34 / 119(28,6 \%)$ & \\
\hline Diabetes & & 0,566 & & 1,0 & & 0,432 & & 0,175 \\
\hline Nem & $60 / 276(21,7 \%)$ & & $23 / 276(8,3 \%)$ & & $58 / 276(21,0 \%)$ & & $64 / 276(23,2 \%)$ & \\
\hline Igen & $12 / 46(26,1 \%)$ & & $3 / 46(6,5 \%)$ & & $7 / 46(15,2 \%)$ & & $6 / 46(13,0 \%)$ & \\
\hline Előző TE-esemény & - & & - & - & & 0,012 & & 0,122 \\
\hline Nem & & & & & $38 / 245(15,5 \%)$ & & $48 / 245(19,6 \%)$ & \\
\hline Igen & & & & & $29 / 106(27,4 \%)$ & & $29 / 106(27,4 \%)$ & \\
\hline
\end{tabular}

*A diagnózis időpontjában mért érték.

A magas, $45-50$, illetve $50-55 \%$ Htc adataink szerint nem volt hatással sem az artériás, sem a vénás TE-eseményekre. Ez jól korrelál az ECLAP tanulmány [8,9] eredményével, ahol $55 \%$ alatti Htc-érték mellett nem látták a TE-események fokozódását, és jelentôsen ellene szól annak a mai gyakorlatnak, hogy szigorúan $45 \%$ alatt kell tartani a Htc értékét [16, 22].

Egyértelmúen megállapíthattuk, hogy a kezelés ellenére/mellett a thrombosiskészség tartósan magas maradt a PV-betegeken. A diagnózist követően szignifikánsan csökkenő major artériás események $(\mathrm{p}<0,0001)$ mögött részben az alkalmazott kezelések hatásossága állhat. Nem zárhatjuk ki azonban az egyre elterjedtebb „intervenciós angiológia” invazív beavatkozásait, illetve a kettős thrombocytaaggregációt, mivel felmérésünk ezekre nem terjedt ki.

A minor artériás TE-események szekunder prevenciójára a jövőben megfontolandónak tartanánk a kardiológusok szerinti kettős thrombocytaaggregáció-gátlást, azonban Tefferi inkább a napi kétszer alkalmazott kis dózisú aszpirint ajánlja [16]. A gyakorlatban ezt nehezen látjuk megvalósíthatónak, hiszen az érkatasztrófák akut szakában betegeinket kardiológusok, illetve neurológusok látják el, és az ő protokolljaik, különösen, ha stentbeültetés is történik, ettől teljesen különböznek és a kettős aggregációgátlást mindenképpen megkövetelik [23-25].
A diagnózist követő vénás TE-események magas száma miatt felvetjük a korábban már vénás TE-eseményen átesett vagy a familiárisan thrombophiliával terhelt PVbetegek tartós (élethossziglan tartó) antikoaguláns kezelését, amely ma a legfrissebb nemzetközi ajánlásnak is feltétele.

Ma nemzetközileg inkább a Tefferi szerinti rizikóbecslés elfogadott, amely a TE-recidíva valószínúségét a betegek magas életkorával és a megelőző TE-eseménnyel jellemzi, ezáltal semmit nem mond a 60 év alatti és megelőző TE-eseményt még el nem szenvedett PV-betegek TE-rizikójáról $[3,10,16]$. Kérdőívünkhöz a Landolfiféle [21] rizikófelmérést azért választottuk, mert a Tefferi-ajánlás két fő tényezője (életkor és megelőző TE-esemény) mellett az általános vascularis rizikófaktorokat is tartalmazza, mint a diabetes mellitus, hypertonia, dyslipidaemia, dohányzás, és az egyes elemeket eltérő mértékben pontozza, valamint a diagnózis idején mért fehérvérsejt- és thrombocytaszámot is figyelembe veszi. Kérdőívünk megszerkesztésekor úgy láttuk, hogy Landolfi-rendszerével a fiatal és TE-eseményeken még át nem esett (Tefferi szerint alacsony rizikójú) PV-betegeink esetében is felbecsülhetjük a vascularis rizikójúakat. Időközben feltehetően maga Tefferi is észlelhette rendszerének ezen betegcsoportra vonatkozó gyengeségét, mert újabb közleményei $[16,22]$ már szintén kitérnek 
az „általános vascularis faktorok” fontosságára, így a két rendszer sokat közeledett egymáshoz.

A betegek alig negyede ( 82 beteg) tartozott az alacsony Landolfi-thrombosisrizikó-csoportba, a rendszer ajánlása szerint ezen betegek nem igényelnek citoreduktív kezelést. A diagnózist követő több mint ötéves időszakban 18 (22\%) betegen észleltünk TE-eseményt, és ezek mindegyike a „túlkezelt” csoportban volt, vagyis a kezelés inkább rontotta a TE előfordulását, bár ez nem volt szignifikáns $(\mathrm{p}=0,5)$. Az alacsony rizikójú PV-betegek korai citoreduktív kezelése ártalmasnak tűnik, az irodalmi adatokkal egyezően magunk sem javasoljuk.

Mivel a Landolfi-ajánlást tartalmazó kérdőívünk csak 2013-tól létezik, ezért a 15 hematológiai centrumban dolgozó kolléga egyéni megítélése (egyéb nemzetközi ajánlások) szerint kezelte betegeit és nem a Landolfiajánlás szerint.

Az alacsony rizikócsoportban inkább phlebotomia és ASA lett volna ajánlható, sajnos a kórlefolyás során 81,3\%-ban HU-kezelést is kaptak, feltehetőleg romló paraméterek miatt.

A Landolfi-rendszer szerint a magas rizikócsoportú 241 betegből 77 esetben (32\%) észleltünk TE-eseményt a diagnózist követő időszakban, amelyek közül 43/77 $(55,8 \%)$ volt recidíva. A két csoport között a TE-események lényegesen magasabb arányban fordultak elő a magas rizikócsoportban, de a különbség nem volt szignifikáns $(\mathrm{p}=0,094)$, ez feltehetően a terápia hatásának tudható be. Szignifikáns különbség csak a minor artériás thrombosisokban volt $(\mathrm{p}=0,048)$.

A Landolfi-rizikófelmérés jól reprezentálta a magas és extrém magas thrombosishajlamot. Bár betegeink az általánosan használt HU + ASA kezelést kapták [3, 14, 15] a diagnózist követően, az emellett bekövetkezett TE-események magas száma felveti, hogy a HU + ASA +/- egyéb kezelés nem elegendő sem az artériás, sem a vénás recidív TE-események prevenciójára. Adataink egyértelműen újabb, hatékonyabb kezelés szükségességére mutatnak rá (JAK-inhibitorok, interferon).

A JAK-inhibitorok szerepét PV-ben több tanulmány is vizsgálta [26-30]. Közülük talán a RESPONSE [26] emelhető ki. A JAK2-inhibitor hatékonyan csökkentette az erythroid proliferációt (Htc phlebotomia nélkül is $45 \%$ alatt maradt), a PV klinikai tüneteit (izzadás, pruritus) és a TE-események előfordulását. A ruxolitinib immunszuppresszív hatása (gyakoribb infekciók - különösen HZV) mellett mérsékelt májfunkciós eltéréseket (emelkedett GOT, GPT és lipidszintek) és hematológiai mellékhatásokat (anaemia és thrombocytopenia) is jelentettek. A szert rezisztens/nonreszponder és relabált (R/R) PV-betegek kezelésére az FDA törzskönyvezte, hazánkban 2017 februárjától elérhető myelofibrosisos és R/R PV-betegek kezelésére.

Az interferonokat régóta alkalmazzuk PV-betegek kezelésére, de igazán nagyszámú betegen végzett randomizált tanulmány helyett inkább csak obszervációs tanulmányok eredményei alapján [31-36]. A konvencionális
IFN-formák mellett gyakori influenzaszerü mellékhatások, depresszió és autoimmun jelenségek miatt sok beteg hagyja abba a kezelést. A modern pegilált szerek heti/ kétheti alkalmazása azonban jól elfogadható, és a jelentôsen csökkent dózis miatt a nemkívánatos hatások is elviselhetőek [36]. Több országban a 60/65 év alatti magas rizikójú PV-betegek első vonalbeli kezelésére elfogadták.

Az átlag ötéves megfigyelés alatt 26 esetben észleltük a PV transzformációját, 24 esetben post-PV-myelofibrosis, egy-egy szekunder AML és malignus lymphoma kialakulását. Haemorrhagiás diathesist 25 esetben regisztráltunk. Az arányok szintén a nemzetközi adatoknak felelnek meg, ezekből további következtetést levonni nem tudunk.

A 900 regisztrált beteg kiértékelését és eredményeink közlését követően kérdőívünket is kiértékeltük. Szerepét lényegében betöltötte, a hazai hematológiai ellátóhelyek adatbevitele jó tájékoztatást adott betegeink epidemiológiai, diagnosztikus, terápiás adatairól, bepillantást nyertünk a TE-eseményekre. Mivel a centrumokat arra kértük, hogy minden gondozott MPN-betegük adatait regisztrálják, így meglehetősen hosszú követési idő alakult ki, amely érdekes következtetések levonására adott lehetőséget. Az előny mellett természetesen hátrány is a hosszú követés, hiszen így a diagnózisok is más-más WHO-ajánlás alapján születtek. Korrigálnunk kellett néhány eddig használt karaktert, mint alacsony, normális, magas. Ezek helyett a tényleges számszerü adatokra (SI mértékrendszerben) alapozunk a továbbiakban.

A további adatbevitelünk a kijavított kérdőívünkkel történik.

A HUMYPRON regiszter elemzése a nemzetközi trendnek megfelelő thromboemboliás és malignus transzformációs eseményeket igazolt. A HU + ASA kezelés mellett szignifikánsan csökkentek a major artériás thromboemboliás események, de az összes TE-esemény nem csökkent. Adataink új, hatékonyabb kezelés szükségességére hívják fel a figyelmet. A ruxolitinib elérhetősége a rezisztens/nonreszponder és relabált betegek részére fontos új lehetőség. Nagy szükség lenne az interferon, fóleg a pegilált IFN elsô vonalbeli alkalmazására fiatal betegek esetében.

Anyagi támogatás: A szerzók anyagi támogatásban nem részesültek.

Szerzôi munkamegosztás: D. P., I. Á., D. J., U. M., K. Á., K. É., V. E., S. Zs., E. M. részt vett a regiszter tartalmi struktúrájának kialakításában, annak frissítésében. H. L. végezte az elektronikus felület kialakítását. H. L., D. P., E. M. végezte a statisztikai számításokat. D. P., I. Á., S. Zs., E. M. és D. J. a kézirat elkészítésében vett részt. A cikk végleges változatát valamennyi szerző elolvasta és jóváhagyta.

Érdekeltségek: A szerzőknek nincsenek érdekeltségeik. 


\section{Köszönetnyilvánítás}

A szerzők köszönetüket fejezik ki Horváth Mónikának, Halász Juditnak, Dr. Jakucs Jánosnak, Dr. Szerafin Lászlónak, Dr. Kiss Miklósnak, Dr. Raposa Tibornak, Dr. Hamvas Józsefnek, Dr. Gasztonyi Zoltánnak, Dr. Bodnár Máriának, Dr. Dömötör Máriának, Dr. Altay Elvirának, Dr. Palaczki Arankának az adatbevitelért és Györiné Korom Viktóriának a segítő együttmúködéséért.

\section{Irodalom}

[1] Vardiman JW, Thiele J, Arber DA, et al. The 2008 revision of the World Health Organization (WHO) classification of myeloid neoplasms and acute leukemia: rationale and important changes. Blood. 2009; 114: 937-951

[2] Langabeer SE, Andrikovics H, Asp J, et al., on behalf of the MPN\&MPNr-EuroNet. Molecular diagnostics of myeloproliferative neoplasms. Eur J Haematol. 2015; 95: 270-279.

[3] Tefferi A. Polycythemia vera and essential thrombocythemia: 2013 update on diagnosis, risk-stratification, and management. Am J Hematol. 2013; 88: 507-516.

[4] Arber DA, Orazi A, Hasserjian R, et al. The 2016 revision to the World Health Organization classification of myeloid neoplasms and acute leukemia. Blood. 2016; 127: 2391-2405.

[5] Moulard O, Mehta J, Fryzek J, et al. Epidemiology of myelofibrosis, essential thrombocythemia, and polycythemia vera in the European Union. Eur J Haematol. 2013; 92: 289-297.

[6] Titmarsh GJ, Duncombe AS, McMullin F, et al. How common are myeloproliferative neoplasms? A systematic review and metaanalysis. Am J Hematol. 2014; 89: 581-587.

[7] Stuart BJ, Viera AJ. Polycythemia vera. Am Fam Physician. 2004; 69: 2139-2144.

[8] Di Nisio M, Barbui T, Di Gennaro L, et al. the European Collaboration on Low-dose Aspirin in Polycythemia Vera (ECLAP) Investigators. The haematocrit and platelet target in polycythemia vera. Br J Haematol. 2007; 136: 249-259.

[9] Landolfi R, Di Gennaro L, Barbui T, et al., for the European Collaboration on Low-Dose Aspirin in Polycythemia Vera (ECLAP). Leukocytosis as a major thrombotic risk factor in patients with polycythemia vera. Blood. 2007; 109: 2446-2452.

[10] Tefferi A, Elliott M. Thrombosis in myeloproliferative disorders: prevalence, prognostic factors, and the role of leukocytes and JAK2V617F. Semin Thromb Hemost. 2007; 33: 313-320.

[11] Egyed M, Illés Á, Demeter J, et al. Iron deficiency significantly contributes to thrombotic risk and to the risk of myelofibrotic transformation in PV and ET patients. Blood. 2015; 126: 5182.

[12] Forejtnikovà $\mathrm{H}$, Vieillevoye $\mathrm{M}$, Zermati $\mathrm{Y}$, et al. Transferrin receptor 2 is a component of the erythropoietin receptor complex and is required for efficient erythropoiesis. Blood. 2010; 116 : 5357-5367.

[13] Rajnics P, Kellner Á, Karádi É, et al. Increased lipocalin 2 level may have important role in thrombotic events in patients with polycythemia vera and essential thrombocythemia. Leuk Res. 2016; 48: 101-106

[14] Tefferi A, Guglielmelli P, Larson DR, et al. Long-term survival and blast transformation in molecularly annotated essential thrombocythemia, polycythemia vera and myelofibrosis. Blood. 2014; 124: 2507-2513.

[15] Finazzi G, Caruso V, Marchioli R, et al., for the ECLAP investigators. Acute leukemia in polycythemia vera: an analysis of 1638 patients enrolled in a prospective observational study. Blood. 2005; 105: 2664-2670.
[16] Tefferi A, Barbui T. Polycythemia vera and essential thrombocythemia: 2017 update on diagnosis, risk-stratification, and management. Am J Hematol. 2017; 92: 94-108.

[17] Barbui T, Finazzi MC, Finazzi G. Front-line therapy in polycythemia vera and essential thrombocythemia. Blood Rev. 2012; 26: 205-211.

[18] Barbui T, Barosi G, Birgegard G, et al. Philadelphia-negative classical myeloproliferative neoplasms: critical concepts and management recommendations from European LeukemiaNet. J Clin Oncol. 2011; 29: 761-770.

[19] Dombi P, Illés Á, Demeter J, et al. Development of the Philadelphia negative chronic myeloproliferative neoplasia registry in Hungary. [Philadelphia-negatív krónikus myeloproliferativ neoplasia regiszter magyarországi létrehozása.] Orv Hetil. 2016; 157: 98-103. [Hungarian]

[20] Gisslinger H, Gotic M, Holowiecki J, et al., ANAHYDRET Study Group. Anagrelide compared to hydroxyurea in WHOclassified essential thrombocythemia: the ANAHYDRET Study, a randomized controlled trial. Blood. 2013; 121: 1720-1728.

[21] Landolfi R, Gennaro L. Prevention of thrombosis in polycythemia vera and essential thrombocythemia. Haematologica. 2008; 93; 331-335.

[22] Tefferi A. Myeloproliferative neoplasms: a decade of discoveries and treatment advances. Am J Hematol. 2016; 91: 50-58.

[23] Becker D, Merkely B. Current therapy of the acute coronary syndrome - 2016. [Akut coronariaszindróma ellátása - 2016.] Orv Hetil. 2016; 157: 1500-1506. [Hungarian]

[24] Levine GN, Bates ER, Bittl JA, et al. 2016 ACC/AHA guideline focused update on duration of dual antiplatelet therapy in patients with coronary artery disease: A report of the American College of Cardiology/American Heart Association Task Force on Clinical Practice Guidelines. J Thorac Cardiovase Surg. 2016; 152: 1243-1275.

[25] Benavente OR, Hart RG, McClure LA, et al. Effects of clopidogrel added to aspirin in patients with recent lacunar stroke. $\mathrm{N}$ Engl J Med. 2012; 367: 817-825.

[26] Verstovsek S, Vannucchi AM, Griesshammer M, et al. Ruxolitinib versus best available therapy in patients with polycythemia vera: 80 -week follow-up from the RESPONSE trial. Haematologica. 2016; 101: 821-829.

[27] Passamonti F, Griesshammer M, Palandri F, et al. Ruxolitinib for the treatment of inadequately controlled polycythaemia vera without splenomegaly (RESPONSE-2): a randomised, open-label, phase 3b study. Lancet Oncol. 2017; 18: 88-99.

[28] Pieri L, Pancrazzi A, Pacilli A, et al. JAK2V617F complete molecular remission in polycythemia vera/essential thrombocythemia patients treated with ruxolitinib. Blood. 2015; 125: 3352-3353.

[29] Vannucchi AM, Kiladjian JJ, Griesshammer M, et al. Ruxolitinib versus standard therapy for the treatment of polycythemia vera. N Engl J Med. 2015; 372: 426-435.

[30] Kiladjian JJ, Winton EF, Talpaz M, et al. Ruxolitinib for the treatment of patients with polycythemia vera. Expert Rev Hematol. $2015 ; 8$ : 391-401

[31] Kiladjian JJ, Cassinat B, Chevret S, et al. Pegylated interferonalfa- $2 \mathrm{a}$ induces complete hematologic and molecular responses with low toxicity in polycythemia vera. Blood. 2008; 112: 30653072 .

[32] Quintás-Cardama A, Abdel-Wahab O, Manshouri T, et al. Molecular analysis of patients with polycythemia vera or essential thrombocythemia receiving pegylated interferon $\alpha-2 \mathrm{a}$. Blood. 2013; 122: 893-901.

[33] Kiladjian JJ, Giraudier S, Cassinat B. Interferon-alpha for the therapy of myeloproliferative neoplasms: targeting the malignant clone. Leukemia. 2016; 30: 776-781. 
[34] Silver RT, Hasselbalch HC. Optimal therapy for polycythemia vera and essential thrombocythemia: preferred use of interferon therapy based on phase 2 trials. Hematology. 2016; 21: 387391.

[35] Hansen IO, Sørensen AL, Hasselbalch HC. Second malignancies in hydroxyurea and interferon-treated Philadelphia-negative myeloproliferative neoplasms. Eur J Haematol. 2017; 98: 75-84.
[36] Crisà $\mathrm{E}$, Cerrano $\mathrm{M}$, Beggiato $\mathrm{E}$, et al. Can pegylated interferon improve the outcome of polycythemia vera patients? J Hematol Oncol. 2017; 10: 15 .

(Egyed Miklós dr., Kaposvár, Tallián Gy. u. 20-32., 7400 e-mail: dregyedmiklos@yahoo.com)

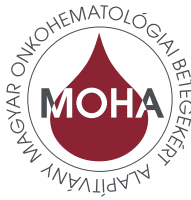

A Magyar Onkohematológiai Betegekért Alapítvány (MOHA) közhasznú civil szervezet, mely azért jött létre, hogy segítse a vérképzöszervi betegségekkel küzdő érintettek hiteles tájékoztatását, érzelmi támogatást nyújtson számukra és képviselje érdekeiket a mindenkori döntéshozók elött.

\section{BETEGEDUKÁCIÓ}

A hematológiai betegségekkel és korszerú kezelési lehetốségekkel kapcsolatos általános, közérthető tájékoztatásban segítjük az érintetteket a legkiválóbb szakemberek bevonásával. Kifejezett célunk a bizonyítékokon alapuló orvoslás iránti bizalom megerósítése és a természettudományos gondolkodás népszerúsítése.

\section{PSZICHOSZOCIÁLIS TÁMOGATÁS}

Támogató csoportjaink célja - az ismeretterjesztésen túl a hasonló problémával küzdő betegek és családtagjaik összefogása, érzelmi támogatása, a bizalmon alapuló orvosbeteg kapcsolat erősítése. A csoporton belül lehetőség van találkozni olyan sorstársakkal, akiknek a példája segítséget nyújthat a sikeres megküzdéshez, a velük való ószinte beszélgetés oldhatja a betegség és a kezelések miatt érzett szorongást.

\section{ÉRDEKÉRVÉNYESÍTÉS}

A MOHA célja, hogy minden érintett megkapja a betegségére ajánlott legkorszerúbb kezelést. Míg az egyes betegek kevéssé tudnak hatékonyan fellépni érdekeik védelmében, addig összefogással, civil nyomásgyakorlással sikert érhetünk el. Az orvostudomány fejlődésének köszönhetôen folyamatosan jelennek meg az új terápiák, amelyek további esélyt adnak a betegeknek. Fontos, hogy az érintettek tudjanak az új lehetóségekről és konzultáljanak arról kezelőorvosukkal! Célunk, hogy a betegek a szükséges gyógyszerekhez minél egyszerúbben, kiszámíthatóan és átláthatóan juthassanak hozzá a megfelelő időben, ezért elvárásunk, hogy az európai gyakorlathoz hasonlóan a betegekkel kapcsolatos döntéshozói folyamatokba vonják be a betegszervezetek képviselőit is.

\section{ELÉRHETŐSÉGEINK}

Magyar Onkohematológiai Betegekért Alapítvány moha@onkohemat.hu,+36 204398645 www.onkohemat.hu, www.facebook.com/onkohemat.hu

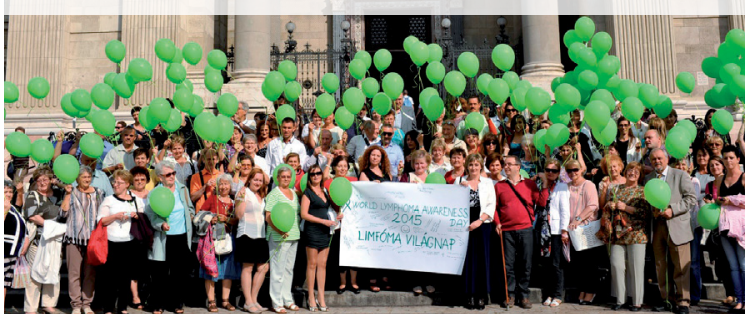

